\title{
Biochemical Impact of Sludge Obtained from Wastewater Treatment Plant on Soil Properties within Port Harcourt Environment
}

\author{
Amadi BA, Akaninwor JO, Igwe FU and Amadi El* \\ Department of Biochemistry, Faculty of Science, University of Port Harcourt, Rivers State, Nigeria
}

\begin{abstract}
A study on the biochemical impact of sludge obtained from wastewater treatment plant on soil properties within PortHarcourt environment were investigated. Parameters such as; $\mathrm{pH}$, temperature, electrical conductivity (EC), nitrogen $(\mathrm{N})$, phosphorus $(\mathrm{P})$, potassium $(\mathrm{K})$, total organic matter (TOM), total organic carbon (TOC), zinc ( $\mathrm{Zn})$, nickel (Ni), and lead $(\mathrm{Pb})$ were assessed in the different soil samples using standard methods, to know the impact of the applied sludge on the biochemical properties of soil. The result showed a significant increase in N, P, K and TOM levels for the test soil $(2.37 \mathrm{mg} / \mathrm{kg}, 32.89 \mathrm{mg} / \mathrm{kg}, 32.15 \mathrm{mg} / \mathrm{kg}$, and $3.12 \mathrm{mg} / \mathrm{kg})$ respectively over the control $(0.93 \mathrm{mg} / \mathrm{kg}, 11.09 \mathrm{mg} / \mathrm{kg}, 36.35$ $\mathrm{mg} / \mathrm{kg}$, and $2.14 \mathrm{mg} / \mathrm{kg}$ ) respectively. $\mathrm{Zn}, \mathrm{Pb}, \mathrm{Ni}$ and TOC which are essential to plants and animals were also found to be significantly higher in the test soil $(19.26 \mathrm{mg} / \mathrm{kg}, 5.71 \mathrm{mg} / \mathrm{kg}, 1.60 \mathrm{mg} / \mathrm{kg}$, and $1.81 \mathrm{mg} / \mathrm{kg})$ respectively over the control $(8.62 \mathrm{mg} / \mathrm{kg}, 2.58 \mathrm{mg} / \mathrm{kg}, 0.52 \mathrm{mg} / \mathrm{kg}$, and $1.24 \mathrm{mg} / \mathrm{kg})$ respectively. The physicochemical, nutrient, and heavy metal parameters of the test soil samples were all significantly different $(p<0.05)$ when compared to their controls. These results revealed that the natural organic fertilizer (sludge) obtained from wastewater treatment plant in Port-Harcourt with its low toxicity level enriched the impacted soil with essential biochemical nutrients such as $\mathrm{N}, \mathrm{P}, \mathrm{K}$, and can be used in place of the very expensive artificial inorganic fertilizer with little cost and side effects for the enrichment of soil nutrient qualities.
\end{abstract}

Keywords: Sludge; Physicochemical; Nutrient; Heavy metals

\section{Introduction}

Land degradation and declining soil fertility are increasingly being viewed as critical problems affecting agricultural productivity and human welfare in tropical Africa [1]. It is estimated that an average of $660 \mathrm{~kg}$ of nitrogen $(\mathrm{N}) \mathrm{ha}^{-1}, 75 \mathrm{~kg}$ of phosphorus $(\mathrm{P}) \mathrm{ha}^{-1}$ and 450 $\mathrm{kg}$ of potassium $(\mathrm{K}) \mathrm{ha}^{-1}$ have been lost during the last 30 years from around 200 million ha of cultivated lands in 37 countries in Sub-Sahara Africa [2]. However, building up and maintaining soil fertility with inorganic fertilizers which are very expensive under the poverty faced by farmers is alarming as the need for addition of external nutrient is imperative. A huge amount of solid wastes generated daily from the various universities, markets, hotels, homes etc, in Nigeria which are usually disposed off either into the sea or land as a solid amendment material can result in the formation of landfill gases, pollution of the receiving waters and water-borne diseases would be widely distributed, thus constituting health hazards to people living around the area [3]. Worldwide, water bodies are the primary dump sites for disposal of waste, especially the effluents from industries that are near them. These effluents from industries have a great toxic influence on the pollution of the water body, as they can alter the physical, chemical and biological nature of the receiving water body [4]. These rivers are now considered environmental health hazards due to the high concentrations of chemical and bacteriological pollution. Despite this, nearly half of the urban populations are at one time or the other, dependent on them as a source of water for domestic use and in worst cases for drinking [5]. Discharge of untreated wastewater into the environment will pollute and decrease water quality in the rivers and soil pollution will occur when used for irrigation. Recently, one of the issues that have attracted the attention of researchers and environmentalists is wastewater chemicals and heavy metals, especially those that can penetrate the soil, plant and finally food chain [6]. Heavy metals represent a portion of important environmental pollutants which causes pollution problems as their use in products have increased in recent decades. In spite of gradual accumulation of heavy metals in the soil, the stability of heavy metals in the environment will cause accumulation and pollution since they could not be decomposed, like organic pollutants, by biological or chemical processes $[7,8]$. These untreated sewage wastescan however be converted into a renewable source of energy (biogas), fuels and other valuable products, such as sludge which can be used to replenish the declining fertility of the soil [9]. Wastewater can originate from the following; human waste (faeces, used toilet paper or wipes, urine, or other bodily fluids), also known as black water, usually from lavatories; cesspit leakage; washing water (personal, clothes, floors, dishes, etc), also known as grey water or sullage; surplus manufactured liquids from domestic sources (drinks, cooking oil, pesticides, lubricating oil, paint, cleaning liquids, etc); highway drainage (oil, de-icing agents, rubber, residues); storm drains (almost anything, including cars, shopping trolleys, trees, cattle etc); urban rainfall runoff from roads, car parks, roofs, sidewalks/pavements (contains oils, animal faeces, litter, gasoline/petrol, diesel, poor rubber residues, soap scum, metals from vehicle exhausts etc); industrial waste; industrial site drainage (silt, sand, alkali, oil, chemical residues); industrial cooling waters (biocides, heat, slimes, silt); industrial process waters; organic or biodegradable waste; including waste from abattoirs, creameries, and ice cream manufactures; organic or non-biodegradable/ difficult-to-treat waste (pharmaceutical or pesticide manufacturing); extreme $\mathrm{pH}$ waste (from acid/alkali manufacturing metal plating); toxic waste (metal plating, cyanide production, pesticide manufacturing); solids and emulsions (paper manufacturing, food stuffs, lubricating

*Corresponding author: Amadi El, Department of Biochemistry, Faculty of Science, University of Port Harcourt, Rivers State, Nigeria, Tel: +234084817941; Email:emmanueldonb@yahoo.com

Received December 01, 2017; Accepted December 22, 2017; Published January 02, 2018

Citation: Amadi BA, Akaninwor JO, Igwe FU, Amadi El (2018) Biochemical Impact of Sludge Obtained from Wastewater Treatment Plant on Soil Properties within Port Harcourt Environment. J Environ Anal Toxicol 8: 540. doi: 10.4172/21610525.1000540

Copyright: @ 2018 Amadi BA, et al. This is an open-access article distributed under the terms of the Creative Commons Attribution License, which permits unrestricted use, distribution, and reproduction in any medium, provided the original author and source are credited. 
Citation: Amadi BA, Akaninwor JO, Igwe FU, Amadi El (2018) Biochemical Impact of Sludge Obtained from Wastewater Treatment Plant on Soil Properties within Port Harcourt Environment. J Environ Anal Toxicol 7: 540. doi: 10.4172/2161-0525.1000540

Page 2 of 5

and hydraulic oil manufacturing); agricultural drainage, direct and diffuse; hydraulic fracturing; produced water from oil and natural gas production [9]. Domestic sewage is mainly comprised of water $(99.9 \%)$ together with moderately small concentrations $(0.1 \%)$ of suspended and dissolved organic and inorganic solids [10]. Sewage sludge is reported to be rich in $\mathrm{N}, \mathrm{P}, \mathrm{K}$, organic matter and trace elements that are beneficial for plant growth and better yield [11]. And it is also considered a suitable substitute for commercial fertilizers as its use in soil conditioning decreases the requirement for commercial fertilizers [12]. Commercial fertilizers require large amount of phosphorus in its composition, whereas phosphorus is known to be a limited resource [13]. Even though the nitrogen available in commercial fertilizers may not be a limited resource, its production requires significant amount of energy [14]. Soils can be contaminated by the accumulation of heavy metals and metalloids through emissions from the rapidly expanding industrial areas; mine tailings; fertilizer applications; animal manures; sewage sludge; pesticides; and wastewater irrigation [15]. Soils are the major sink for heavy metals released into the environment by anthropogenic activities and unlike organic contaminants which are oxidized to $\mathrm{CO}_{2}$ by microbial action, most metals do not undergo microbial or chemical degradation [16], and their concentration persists for a long time after their introduction [17]. Changes in their chemical forms (speciation) and bioavailability are, however possible. The high level of heavy metals in the soil could indicate similar concentration in plant by accumulation at concentrations causing serious risk to human health when consumed [18]. Plants are exposed to heavy metals through the uptake of water; animals eat these plants; ingestion of plant-and -animal-based foods is the largest sources of heavy metals in human [19]. Heavy metals can accumulate in organisms as they are hard to metabolize (process and eliminate) [20]. The study was therefore carried out to investigate potential biochemical impact of natural organic fertilizer (sludge) that can be used to replace very expensive artificial inorganic fertilizer with little cost and side effects.

\section{Materials and Methods}

Soil samples were collected using a hand soil auger in random replicates of three, at $20 \mathrm{~cm}$ depth and were bulked to form a composite sample from the control site (vegetable farm with zero sludge application) and test site (wastewater treatment plant with sludge used as soil amendment), both in Port Harcourt City Local Government Area, Rivers State, Nigeria. The samples were air-dried under room temperature to ensure constant weight for 3 days. They were homogenized using a ceramic mortar and pestle to obtain finer texture and to remove sticks, pebbles and rock particles. The homogenized soil samples were then sieved through a $2 \mathrm{~mm}$ polythene sieve and stored in a sample container prior to analysis according to Singh et al. [18]. A $5.0 \mathrm{~g}$ of the sieved sample was accurately put into the flask and ignited in a muffle furnace for $6 \mathrm{hr}$, opening the cover for escape of gases at $500^{\circ} \mathrm{C}$. This was checked periodically until complete ashing (a greywhite ash) was obtained. The ashed samples were allowed to cool in a desiccator, and $5 \mathrm{ml}$ of $10 \% \mathrm{HCl}$ was added to each sample to enhance dissolution, and $5 \mathrm{ml}$ of $10 \% \mathrm{HNO}_{3}$ was added thereafter and set on a water bath to dissolve completely. The solution was evaporated to near dryness on the water bath. On cooling to room temperature, the digest was filtered through what man no. 42 filter paper, into a clean, dry $50 \mathrm{ml}$ standard volumetric flask. Both the dish and the filter paper were washed into the flasks, made up to mark with deionized water. The resultant solutions from the respective digestions were kept in the refrigerator prior to metal analysis.

\section{Analytical procedure}

A multi-parameter (HI 98129) was used to determine the $\mathrm{pH}$ as well as the temperature, total dissolved solids and electrical conductivity of the samples. The multi-parameter was calibrated using the manufacturer's standard reagents.

Nitrogen: $\mathrm{N}$ was determined by macro kjeldahl method. $2.0 \mathrm{~g}$ of air-dried soil sample was digested using a dry $500 \mathrm{ml}$ macro kjeldahl digestion flask and subsequently followed by distillation. Thereafter, $150 \mathrm{ml}$ of the distillate was collected. The $\mathrm{NH}_{4}-\mathrm{N}$ in the distillate was determined by titrating with $0.01 \mathrm{~N} \mathrm{HCl}$. The color change at the end point was from green to pink. Thereafter, the percentage content of nitrogen in the soil was calculated [21].

Phosphorus: P was determined by Ascorbic acid method. The absorbance of each sample was read at $880 \mathrm{~nm}$, using a Vis S23A spectrophotometer with infrared phototube and light path of $2.5 \mathrm{~cm}$, and phosphorus was calculated [21].

Organic carbon: $\mathrm{OC}$ was determined by Wet oxidation method. The organic carbon was oxidized by $\mathrm{K}_{2} \mathrm{Cr}_{2} \mathrm{O}_{7}$ in the presence of $\mathrm{H}_{2} \mathrm{SO}_{4}$ leading to the formation of $\mathrm{O}_{2}$ according to the equation given below:

$$
2 \mathrm{~K}_{2} \mathrm{Cr}_{2} \mathrm{O}_{7}+8 \mathrm{H}_{2} \mathrm{SO}_{4} \rightarrow 2 \mathrm{~K}_{2} \mathrm{SO}_{4}+2 \mathrm{Cr}_{2}\left(\mathrm{SO}_{4}\right)_{3}+8 \mathrm{H}_{2} \mathrm{O}+3 \mathrm{O}_{2}
$$

The solution was titrated using ferrous ammonium sulphate while swirling the flask until color changes from blue violet to green was observed. The burette reading was recorded, and then $0.5 \mathrm{ml}$ of 1 $\mathrm{N} \mathrm{K}_{2} \mathrm{Cr}_{2} \mathrm{O}_{7}$ was added to the solution and titrated again with ferrous ammonium sulphate to the same end point. The burette reading was recorded and organic carbon was calculated [22].

Heavy metal: $\mathrm{HM}$ contents in the samples were determined by digestion method using GBC-Avanta PM AAS [23]. The digested sample was introduced into the AAS by direct aspiration after calibration. The results were expressed as mean \pm standard deviation of the mean (SD) in triplicates. All the data obtained were subjected to the statistical ANOVA analysis of the mean, using computer aided statistical package for the social sciences (SPSS) version 20.

\section{Results and Discussion}

The result of physicochemical parameters of the sample is shown in Tables 1 and 2 shows the results of nutrient parameters. The heavy metal parameters are shown in Table 3 .

A significant increase $(\mathrm{p}<0.05)$ was observed in the $\mathrm{pH}$ of the test soil sample (6.94) over the control (6.66) as shown in Table 1. This result implies that acidic soils can experience increase in $\mathrm{pH}$ following sludge amendment due to the exchangeable calcium and other cations present in sewage sludge [24-26]. The presence of ammonium in the inorganic fertilizers usually reduces soil $\mathrm{pH}$ and increases the rate of soil acidification as well as increase the percentage of aluminum saturation [27]. This study is suggestive that the sludge is suitable and more preferable to the inorganic fertilizer due to its $\mathrm{pH}$ increasing capacity and thus recommended for application as fertilizer.

There was a significant increase $(\mathrm{p}<0.05)$ in the total dissolved solid (TDS) of the test soil $(96.67 \mathrm{mg} / \mathrm{l})$ over the control $(20.67 \mathrm{mg} / \mathrm{l})$ as shown in Table 1. This observed increase may be attributed to the accumulation of soluble salt in the lower layers of the soil due to leaching as reported by Abu-Awwad et al. [28]. This trend suggests a significant contribution from the TDS of the sludge $(1190.67 \mathrm{mg} / \mathrm{l})$ to the soil TDS as seen in Table 1 . There was also a significant increase $(\mathrm{p}<0.05)$ in the electrical conductivity $(\mathrm{EC})$ of the test soil $(194.00 \mathrm{uS} /$ 
Citation: Amadi BA, Akaninwor JO, Igwe FU, Amadi El (2018) Biochemical Impact of Sludge Obtained from Wastewater Treatment Plant on Soil Properties within Port Harcourt Environment. J Environ Anal Toxicol 7: 540. doi: 10.4172/2161-0525.1000540

Page 3 of 5

\begin{tabular}{|c|c|c|c|}
\hline Parameters & Sludge & Control soil & Test soil \\
\hline $\mathrm{pH}$ & $5.86 \pm 0.13$ & $6.66 \pm 0.14$ & $6.94 \pm 0.10^{*}$ \\
\hline Temperature $\left({ }^{\circ} \mathrm{C}\right)$ & $27.20 \pm 0.10$ & $28.17 \pm 0.06$ & $28.00 \pm 0.00^{*}$ \\
\hline TDS $(\mathrm{mg} / \mathrm{l})$ & $1190.67 \pm 19.76$ & $20.67 \pm 0.58$ & $96.67 \pm 0.58^{*}$ \\
\hline $\mathrm{EC}(\mathrm{uS} / \mathrm{cm})$ & $2350.00 \pm 19.96$ & $42.00 \pm 0.00$ & $194.00 \pm 1.73^{*}$ \\
\hline
\end{tabular}

Values are expressed as mean \pm standard deviation of triplicate determinations $(n=3)$. Key: asterisks $\left(^{*}\right)$ denotes significant difference at $(p<0.05)$.

Table 1: Physico-chemical parameters investigated on the different soil samples.

\begin{tabular}{|c|c|c|c|}
\hline Parameters & Sludge & Control soil & Test soil \\
\hline Nitrogen (N) & $2.63 \pm 0.65$ & $0.93 \pm 0.04$ & $2.37 \pm 0.07^{*}$ \\
\hline Phosphorus (P) & $20.32 \pm 3.65$ & $11.09 \pm 1.15$ & $32.89 \pm 2.62^{*}$ \\
\hline Potassium (K) & $208.69 \pm 0.02$ & $36.35 \pm 0.23$ & $32.15 \pm 0.05^{*}$ \\
\hline Total organic matter (TOM) & $0.48 \pm 0.04$ & $2.14 \pm 0.03$ & $3.12 \pm 0.24^{*}$ \\
\hline
\end{tabular}

Values are expressed as mean \pm standard deviation of triplicate determinations $(n=3)$. Key: asterisks $\left(^{*}\right)$ denotes significant difference at $(p<0.05)$.

Table 2: Nutrient parameters investigated on the different soil samples in $\mathrm{mg} / \mathrm{kg}$.

\begin{tabular}{|c|c|c|c|}
\hline Parameters & Sludge & Control soil & Test soil \\
\hline Zinc $(\mathrm{Zn})$ & $31.70 \pm 0.04$ & $8.62 \pm 0.19$ & $19.26 \pm 0.06^{*}$ \\
\hline Nickel $(\mathrm{Ni})$ & $2.66 \pm 0.03$ & $0.52 \pm 0.03$ & $1.60 \pm 0.13^{*}$ \\
\hline Lead $(\mathrm{Pb})$ & $11.14 \pm 0.02$ & $2.58 \pm 0.10$ & $5.71 \pm 0.16^{*}$ \\
\hline Total organic carbon $(\mathrm{TOC})$ & $0.28 \pm 0.02$ & $1.24 \pm 0.02$ & $1.81 \pm 0.14^{*}$ \\
\hline
\end{tabular}

Values are expressed as mean \pm standard deviation of triplicate determinations $(n=3)$. Key: asterisks $\left(^{*}\right)$ denotes significant difference at $(p<0.05)$.

Table 3: Heavy metal parameters investigated on the different soil samples in $\mathrm{mg} /$ $\mathrm{kg}$.

$\mathrm{cm})$ when compared to the control $(42.00 \mathrm{uS} / \mathrm{cm})$ as shown in Table 1. This observed increasemay be attributed to the formation of complexes of organic matter and heavy metals also known as metallic salts [28]. This trends also suggests a significant contribution from the EC of the sludge $(2350.00 \mathrm{uS} / \mathrm{cm})$ to the test soil EC as seen in Table 1.

There was a significant increase $(\mathrm{p}<0.05)$ in the nitrogen $(\mathrm{N})$ content of the test soil $(2.37 \mathrm{mg} / \mathrm{kg})$ over the control $(0.93 \mathrm{mg} / \mathrm{kg})$ as shown in Table 2. This increase is expected as the sludge may have contributed its $\mathrm{N}(2.63 \mathrm{mg} / \mathrm{kg})$ to increasing the soil nitrogen content of the test soil due to high concentration of urea and nitrogen found in sewage. This is in accordance with reports by Monnett et al. [29,30] and Bernala et al. [31]. Nitrogen is an essential nutrient for plant growth since it is a constituent of all proteins and nucleic acids [32]. Normally crop yield increases with increase in the application of sewage sludge, and nitrogen is often the rate limiting factor in the application of sewage sludge to agricultural lands. The content of total nitrogen in sewage sludge reaches $40-50 \mathrm{~kg} /$ ton [32]. Only a small part of the total nitrogen is immediately available for plants after application of sewage sludge whereas the reverse is the case on the inorganic fertilizer. In the course of mineralization of sewage sludge, nitrogen is transformed into available forms. Sludge decomposition is reported to occur within 28 days. The amount of nitrogen mineralized is inversely proportional to the carbon to nitrogen $(\mathrm{C} / \mathrm{N}$ ratio). Soils with large $\mathrm{C} / \mathrm{N}$ ratio result in low quantities of mineralized nitrogen [33-35]. Inorganic fertilizers by contrast increase the $\mathrm{C} / \mathrm{N}$ ratio which increases organic matter mineralization and nitrate leaching [36].

The phosphorus (P) content of the test soil $(32.89 \mathrm{mg} / \mathrm{kg})$ showed a significant increase $(\mathrm{p}<0.05)$ over the control $(11.09 \mathrm{mg} / \mathrm{kg})$ as shown in Table 2. This increase is expected as the sludge may have contributed its $\mathrm{P}(20.32 \mathrm{mg} / \mathrm{kg})$ to increasing the soil phosphorus content of the test soil. Phosphorus is an essential nutrient needed for plant growth and is required in large quantities by plants while it is relatively immobile in soils. Phosphorus availability can be as high as $50 \%$ in the application of sewage sludge. Nyamangara et al. [37] reported phosphorus increase in sludge amended soils from 2-4 mg/ $\mathrm{kg}$ to $29-114 \mathrm{mg} / \mathrm{kg}$ which is in accordance with the result obtained in this study. Soil phosphorus availability can be reduced in low $\mathrm{pH}$ soils in which the organic matter in the soil carries a positive charge attracting phosphorus and causing immobilization. Plantation growth in such low phosphorus environment leads to poor yield [38]. Sludge amendment with or without lime addition can provide extra buffering against soil acidity and reduce the inhibitory effects of sewage sludge especially on the availability of heavy metals [26,39-41]. Organisms involved in biological activities in the soil require phosphorus for the production and synthesis of new cell tissues. This anion is also known to stimulate root growth in plants. Phosphate helps in the formation of nucleic proteins and co-enzymes for plants. Hence, its suitability for irrigation in a phosphate deficient soil [42].

A significant difference $(\mathrm{p}<0.05)$ in the potassium $(\mathrm{K})$ content of the test soil $(32.15 \mathrm{mg} / \mathrm{kg})$ was observed when compared to the control $(36.35 \mathrm{mg} / \mathrm{kg}$ ) as shown in Table 2. This observed decrease may be attributed to mineral uptake by crops deficient in $\mathrm{K}$ within the area of study as the sludge may have contributed its $\mathrm{K}(208.69 \mathrm{mg} / \mathrm{kg})$ to the overall build-up of the crops as seen in Table 2. The total organic matter for the test soil $(3.12 \mathrm{mg} / \mathrm{kg})$ showed a significant increase $(\mathrm{p}<0.05)$ when compared to the control $(2.14 \mathrm{mg} / \mathrm{kg})$ as shown in Table 2 . This may be due to high organic matter content in the sludge $(0.48 \mathrm{mg} / \mathrm{kg})$ as seen in Table 2, indicating the sludge's importance. An increase in organic matter reduces the bulk density, increases water holding capacity of soils, increases aggregate stability, and promotes greater water infiltration [43]. Organic matter also influences nutrient storage and turnover, soil biota and diversity as well as vulnerability to erosion [44], infiltration capacity and air recirculation increase in fine textured soils as a result of sludge application $[45,46]$. By contrast, the increased bulk density of fine textured soils without sludge amendment causes poor aeration which adversely affects plant growth [47]. Sewage sludge is reported to be rich in $\mathrm{N}, \mathrm{P}, \mathrm{K}$, organic matter and trace elements that are beneficial for plant growth and better yield [11]. And it is also considered a suitable substitute for commercial fertilizers as its use in soil conditioning decreases the requirement for commercial fertilizers [12]. Commercial fertilizers require large amount of phosphorus in its composition, whereas phosphorus is known to be a limited resource [13]. Even though the nitrogen available in commercial fertilizers may not be a limited resource, its production requires significant amount of energy [14].

There was a significant increase $(\mathrm{p}<0.05)$ in the zinc $(\mathrm{Zn})$ content of the test soil $(19.26 \mathrm{mg} / \mathrm{kg})$ over the control $(8.62 \mathrm{mg} / \mathrm{kg})$ as shown in Table 3. The major sources of zinc in this site is probably the attrition of soaps, detergents, lubricating oils, found in wastewater which zinc is found as part of many additives as zinc dithiophosphates [48]. Zinc is essential to plants and animals in very low concentrations by serving as components of enzymes, structural proteins, pigments and also helping to maintain the ionic balance of cells. These and other trace elements are important for proper functioning of biological systems. Even though zinc is an essential requirement for a healthy body, excess zinc above $25 \mathrm{mg} / \mathrm{kg}$ can be harmful, and cause zinc toxicity [49]. Nickel $(\mathrm{Ni})$ showed a significant increase $(\mathrm{p}<0.05)$ in the test soil $(1.60 \mathrm{mg} / \mathrm{kg})$ over the control $(0.52 \mathrm{mg} / \mathrm{kg})$ as seen in Table 3 . This may be due to accumulation of heavy metals from the sludge [50]. The 
Citation: Amadi BA, Akaninwor JO, Igwe FU, Amadi El (2018) Biochemical Impact of Sludge Obtained from Wastewater Treatment Plant on Soil Properties within Port Harcourt Environment. J Environ Anal Toxicol 7: 540. doi: 10.4172/2161-0525.1000540

Page 4 of 5

supply of various bio-solids for example: composts, cattle's manure and municipal sewage sludge (MSS) to land unconsciously points towards the build-up of heavy metals like nickel in the soil [51]. Heavy metals most usually established in bio-solids include $\mathrm{Ni}, \mathrm{Pb}, \mathrm{Zn}, \mathrm{Cr}, \mathrm{Cu}$, and $\mathrm{Cd}$, and the metal contents are ruled by nature and the strength of the industrial processes. Under specific situations, metals supplied to soils by applying bio-solids can be percolated downwards by the soil horizons and may have the ability to pollute groundwater [52]. There were also a significant increase $(\mathrm{p}<0.05)$ in the lead $(\mathrm{Pb})$ and total organic carbon (TOC) for the test soil $(5.71 \mathrm{mg} / \mathrm{kg} ; 1.81 \mathrm{mg} / \mathrm{kg}$ ) respectively when compared to the control $(2.58 \mathrm{mg} / \mathrm{kg} ; 1.24 \mathrm{mg} / \mathrm{kg})$ respectively as shown in Table 3 . This is in accordance with previous reports by Seaker et al. [53,54] who reported that organic carbon in sludge amended soil can increase as far as three-fold compared to inorganic fertilizer amended soils.

\section{Conclusion}

The results of this study revealed that sludge obtained from wastewater treatment plant in Port-Harcourt contains high amount of micro and macro nutrients that are essential and required for plant and soil fauna. Its application to soil has biochemical impact on the quality, structure and properties of the soil to cultivable land, and hence it is suitable and more preferable to the inorganic fertilizer.

\section{References}

1. Osundare OT, Fajinmi AA, Okonji CJ (2015) Effects of organic and inorganic soil amendments on growth performance of plantain (Musa paradisiacal L). African Journal of Agricultural Research 10: 154-160.

2. Stoorvogel JJ, Smaaling EM (1993) Calculating soil nutrient balances in Africa I Supranational scale. Fertilizer Res 35: 227-235.

3. Dioha IJ, Umar MK, Eboatu AM, Okoye PAC (2005) Comparative studies of the qualitative and quantitative yields of biogas from cow dung and poultry droppings. Niger J Solar Energy 15: 60-66.

4. Adekunle AS, Eniola IT (2008) Impact of industrial effluents on quality of segment of Asa river within an industrial estate in Ilorin, Nigeria. New York Science Journal 1: 17-21.

5. Kahara NS (2002) Characterizing anthropogenic sources of pollution for tropical urban river management. A proposed case study of the Nairobi river basin, p: 87 .

6. Ashworth DJ, Alloway BJ (2003) Soil mobility of sewage sludge-derived dissolved organic matter, copper, nickel and zinc. Environmental Pollution 127: $137-144$

7. Mcbride MB (1995) Toxic metal accumulation from agricultural use of sludge: the USEPA regulations protective. Journal of Environmental Quality 24: 5-18.

8. Oyinlola AK (2001) Recycling/resource recovery technology option for a sustainable solid waste management system in Nigeria, pp: 63-72.

9. Tilley E (2014) Compendium of sanitation systems and technologies. 2nd edn. Swiss Federal Institute of Aquatic Science and Technology (eawag), Duebendorf, Switzerland, p: 175

10. Mara D, Cairncross S (1989) Guidelines for the safe use of waste water and excreta in agriculture and aquaculture. World Health Organization.

11. Kauthale VK, Takawale PS, Kulkarni PK, Daniel LN (2005) Influence of flyash and sewage sludge application on growth and yield of annual crops. International Journal of Tropical Agriculture 23: 49-54.

12. Richards BK, Steenhuis TS, Peverly JH, McBride MB (1998) Metal mobility at an old, heavily loaded sludge application site. Env Poll 89: 365-377.

13. USEPA (1995) Process design manual, land application of sewage sludge and domestic septage. US Environmental Protection Agency, Office of Research and Development, EPA-625/r-95/001, Cincinnati, Ohio, USA.

14. UNEP (1996) Mineral fertilizer production and the environment, a guide to reducing the environmental impact form fertilizer production. Technical report no. 26, United Nations Environmental Programme, Industry and the Environment, Paris, France.
15. Zhang J, Michael S, Axel S (2010) Arctic sea ice response to atmospheric forcings with varying levels of anthropogenic warming and climate variability. Geophysical Research Letters 3: 20.

16. Kirpichtchikova TA, Manceau A, Spadini L, Panfili F, Marcus MA, et al. (2006) Speciation and solubility of heavy metals in contaminated soil using x-ray microfluorescence, exafs spectroscopy, chemical extraction and thermodynamics modelling. Geochemical et Cosmo Chimica Acta 70: 21632190.

17. Adriano DC (2003) Trace elements in terrestrial environments. Biogeochemistry, bioavailability and risks of metals. 2nd edn. New York: Springer.

18. Singh A, Sharma RK, Agrawal M, Marshall FM (2010) Health risk assessment of heavy metals via dietary intake of foodstuffs from the wastewater irrigated site of a dry tropical area of India. Food Chem Toxicol 48: 611-619.

19. Radojević M, Bashkin VN (1999) Practical environmental analysis. 2nd edn. The Royal Society of Chemistry, Cambridge, UK.

20. Pezzarossa B, Gorini F, Petruzzelli G (2011) Heavy metal and selenium distribution and bioavailability in contaminated sites: a tool for phytoremediation Dynamics and bioavailability of heavy metals in the rootzone. CRC Press, Taylor \& Francis Group 15: 93-127.

21. American Public Health Association (APHA) (1992) Standard methods of water and wastewater examination. 18th edn. New York, Washington DC, USA.

22. Walkley A, Black IA (1934) An examination of degtjareff method for determining soil organic matter and a proposed modification of the chromic acid titration method. Soil Sci 37: 29-37.

23. American Society for Testing and Materials (ASTM) (2003) Standard methods of analysis.

24. Tsadilas CD, Matsi T, Barbayiannis N, Dimoyiannis D (1995) Influence of sewage sludge application on soil properties and on the distribution an availability of heavy metal fractions. Commun Soil Sci Plant Anal 26: 2603 2619.

25. Parkpain P, Sreesai S, Delaune RD (2000) Bioavailability of heavy metals in sewage sludge amended Thai soils. Water, Air and Soil Pollution 122: 163-182.

26. Wong JW, Lai KM, Su DS, Fang M (2001) Availability of heavy metals for Brassica chinensis grown in an acidic loamy soil amended with a domestic and an industrial sewage sludge. Water, Air \& Soil Pollution 128: 339-353.

27. Mulvaney RL, Khan SA, Mulvaney CS (1997) Nitrogen fertilizers promote denitrification. Biolfertil Soils 24: 211-220.

28. Abu-Awwad AM (1996) Irrigation water management for onion tricle irrigated with saline drainage water. Dirasat 23: 46-55.

29. Monnett GT, Reneau RB, Hagedorn C (1996) Evaluation of spray irrigation for on-site wastewater treatment and disposal on marginal soils. Water Environmental Research 68: 11-18.

30. Ramirez-Fuentes E, Lucho-Constantino C, Escamilla-Silva E, Dendooven L (2002) Characteristics, and carbon and nitrogen dynamics in soil irrigated with wastewater for different lengths of time. Bioresource Technology 85: 179-187.

31. Alvarez-Bernal D, Contreras-Ramos SM, Trujillo-Tapia N, Olalde-Portugal V, Frías-Hernández JT, et al. (2006) Effects of tanneries wastewater on chemical and biological soil characteristics. Applied Soil Ecology 33: 269-277.

32. Stark SA, Clapp CE (1980) Residual nitrogen availability from soils treated with sewage sludge in a field experiment. Journal of Environmental Quality 9: 505512.

33. Pakhnenko EP, Ermakov AV, Ubugunov LL (2009) Influence of sewage sludge from sludge beds of Ulan-Ude on the soil properties and the yield and quality of potatoes. Moscow University Soil Science Bulletin 64: 175-181.

34. Kowalenko CG, Lowe LE (1975) Mineralization of sulfur from four soils and its relationship to soil carbon, nitrogen and phosphorus. Canadian Journal of Soil Science 55: 9-14.

35. Terry RE, Nelson DW, Sommers LE (1979) Carbon cycling during sewage sludge decomposition in soils. Soil Science Society of America Journal 43: 494-499.

36. Whitehead DC (1995) Grassland nitrogen. Cab International, Wallingford.

37. Nyamangara J, Mzezewa J (2001) Effect of long-term application of sewage sludge to a grazed grass pasture on organic carbon and nutrients of a clay soil 
Citation: Amadi BA, Akaninwor JO, Igwe FU, Amadi El (2018) Biochemical Impact of Sludge Obtained from Wastewater Treatment Plant on Soil Properties within Port Harcourt Environment. J Environ Anal Toxicol 7: 540. doi: 10.4172/2161-0525.1000540

in Zimbabwe. Nutrient Cycling in Agroecosystems 59: 13-18.

38. López-Díaz ML, Mosquera-Losada MR, Rigueiro-Rodríguez A (2007) Lime, sewage sludge and mineral fertilization in a silvopastoral system developed in very acid soils. Agroforestry Systems 70: 91-101.

39. Fotovat A, Naidu R, Sumner ME (1997) Water: soil ratio influences aqueous phase chemistry of indigenous copper and zinc in soils. Soil Research 35: 687710

40. Gherardi MJ, Rengel Z (2003) Deep placement of manganese fertiliser improves sustainability of lucerne growing on bauxite residue: A glasshouse study. Plant and Soil 257: 85-95.

41. Mtshali JS, Tiruneh AT, Fadiran AO (2014) Characterization of sewage sludge generated from wastewater treatment plants in Swaziland in relation to agricultural uses. Resources and Environment 4: 190-199.

42. Sangodoyin AY (1991) Ground and surface water pollution by open refuse dump in Ibadan, Nigeria. Discovery and Innovation 3: 37-43.

43. Kladivko EJ, Nelson DW (1979) Changes in soil properties from application of anaerobic sludge. Journal Water Pollution Control Federation 1: 325-332.

44. Bullock P, Burton RG (1996) Organic matter levels and trends in the soils of England and Wales. Soil Use Mgmt 12: 103-104.

45. Stucky DJ, Newman TS (1977) Effect of dried anaerobically digested sewage sludge on yield and element accumulation in tall fescue and alfalfa. Journal of Environmental Quality 6: 271-274

46. Garcia WJ, Blessin CW, Inglett GE, Kwolek WF, Carlisle JN, et al. (1981) Metal accumulation and crop yield for a variety of edible crops grown in diverse soil media amended with sewage sludge. Environmental Science \& Technology 15: 793-804.

47. Forbes JC, Watson RD (1992) Plants in agriculture. Cambridge, Cambridge University Press.

48. Priscilla A (2015) Assessment of heavy metals in roadside surface soil and vegetation along mubi -michika major road in Adamawa State, Nigeria. International Journal of Applied Science and Biotechnology 3: 545-551.

49. Kosolapov DB, Kuschk P, Vainshtein MB, Vatsourina AV, Wiessner A, et al (2004) Microbial processes of heavy metal removal from carbon-deficient effluents in constructed wetlands. Engineering in Life Sciences 4: 403-411.

50. Idodo-Umeh G, Ogbeibu AE (2010) Bioaccumulation of the heavy metal in cassava tubers and plantain fruits grown in soils impacted with petroleum and non-petroleum activities. Res J Env Sci 4: 33-41.

51. Basta NE, Halloran ME, Matrajt L, Longini IM (2008) Estimating influenza vaccine efficacy from challenge and community-based study data. American Journal of Epidemiology 168: 1343-1352.

52. Mattigold SV, Page AL (1963) Assessment of metal pollution in soil. Applied Environmental Geochemistry, pp: 355-394.

53. Seaker EM, Sopper WE (1988) Municipal sludge for minespoil reclamation: II. Effects on organic matter. Journal of Environmental Quality 17: 598-602.

54. da Fonseca AF, Melfi AJ, Montes CR (2005) Maize growth and changes in soi fertility after irrigation with treated sewage effluent. I. Plant dry matter yield and soil nitrogen and phosphorus availability. Communications in Soil Science and Plant Analysis 36: 1965-1981. 